\title{
Peran Pemerintah Daerah dalam Mengawasi Takaran dan Timbangan dari Perspektif Ekonomi Syariah
}

\author{
Tezi Asmadia \\ Institut Agama Islam Negeri Batusangkar \\ Email: teziasmadia@iainbatusangkar.ac.id \\ Jl. Jenderal Sudirman No.137, Limo Kaum Kab. Tanah Datar, Sumatera Barat
}

\begin{abstract}
Abstrak
Penelitian ini bertujuan untuk mengetahui bagaimana peran pemerintah kota Padang Panjang dalam mengawasi takaran dan timbangan di pasar Padang Panjang. Penelitian ini menggunakan pendekatan deskriptif kualitatif. Teknik pengumpulan data menggunakan observasi, wawancara, dokumentasi, dan kuesioner. Analisis data yang digunakan adalah metode deskriptif kualitatif. Dengan cara mengumpulkan data berupa dokumen, arsip dan hasil wawancara. Hasil penelitian ini adalah: (1) pengawasan terhadap takaran dan timbangan di Kota Padang Panjang hanya merambah dari segi keabsahan dan kebenaran alat-alat ukur, takar dan timbangan yang dipakai para pedagang, tidak merambah pada perilaku dan cara pedagang mempergunakan alat alat tersebut, (2) dalam hal pengawasan, dilakukan oleh tenaga UPTD provinsi yang juga melakukan pembinaan dan peneraan. Hal ini disebabkan oleh sumber daya manusia yang kurang memadai , dan (3) pedagang pasar Padang Panjang cukup paham dalam menggunakan takaran dan timbangan yang benar sesuai dengan ekonomi Islam.
\end{abstract}

Kata kunci: Pemerintah Daerah, Takaran, Timbangan

\begin{abstract}
This study aims to determine how the rolr of the Padang Panjang city government in overseeing the measurements and scales in the Padang Panjang Market. This research uses descriptive qualitative and quantitative approaches. Data collection techniques using observation, interviews, documentation, and questionnaires. Data analysis in this study used descriptive qualitative and quantitative methods. By collecting data in the form of documents, archives, interviews and questionnaires. The results of this study are: (1) monitoring of measurements and scales in the city of Padang Panjang only penetrates in terms of the validity and correctness of measuring instruments, measurements and scales used by traders, not encroaching on the behavior and ways of traders using these tools, (2) in terms of supervision, it still uses provincial UPTD staff which basivally also conducts guidance and illumination. In this case, human resources is indeed an issue, and (3) Padang Panjang market traders are well-versed in using the correct measurements and scales in accordance with Islamic economics.
\end{abstract}

Keywords: regional government, measure, scale 


\section{Peran Pemerintah Daerah dalam Mengawasi Takaran dan Timbangan dari Perspektif Ekonomi Syariah}

Tezi Asmadia

\section{Pendahuluan}

Dalam ekonomi Islam masalah ukuran, takaran, dan timbangan merupakan tugas dan wewenang negara. Di Indonesia, instansi yang ditunjuk untuk melaksanakan tugas itu adalah Direktorat Metrologi atau Balai Metrologi yang berada di bawah Kantor Departemen Perdagangan Dalam Negeri.(Rozalinda, 2014) Tugas-tugas dari Balai Metrologi memiliki peranan penting untuk terciptanya tertib ukur sehingga dapat mewujudkan tertib niaga dan perlindungan konsumen. Sehingga kecurangan dalam ukuran, takaran, dan timbangan dapat dicegah.

Realita yang terjadi di masyarakat kini keadaannya sangat memprihatinkan. Ada di antara mereka yang terbiasa mengurangi atau mengubah timbangan dan takarannya dari bentuk yang normal. Seperti yang penulis temukan saat membeli sebuah komoditi, berat komoditi yang penulis beli tidak sesuai dengan yang sebenarnya setelah penulis menguji di tempat lain. Demi keuntungan yang cukup besar dan menjanjikan, pedagang tersebut rela menerobos rel-rel syari'at yang telah ditetapkan. Pedagang sama sekali tidak memperhatikan kepuasan dan kekecewaan pembeli. Padahal dalam transaksi, penjual dan pembeli sama-sama mempunyai hak yang harus dipenuhi satu sama lain.

Secara sosial, kondisi penjualan semacam ini akan mengantarkan terhadap ketidakharmonisan antara penjual dan pembeli. Pembeli tidak mau untuk kembali membeli barang-barangnya. Mereka akan meminta pertanggungjawaban atas apa yang telah diperlakukan kepada dirinya. Sementara jika ditinjau dari aspek hukum, tentu penjualan semacam ini tidak dibenarkan oleh syari'at. Apapun alasannya, kalau di antara hak penjual dan pembeli tidak terpenuhi maka suatu transaksi dinyatakan tidak sah.

Pasar tradisional Kota Padang Panjang merupakan salah satu pasar yang berada di Sumatera Barat, yang dahulunya pada masa Kerajaan Pagaruyung perdagangan di kota ini sangat lancar. Pedagang yang masuk ke sini, antara lain dari Hindia, Parsi, Gujarat, Timur Tengah dan Eropa. Waktu itu, kemakmuran masyarakat Minangkabau dapat dilihat dari suasana yang terjadi di Pasar Padang Panjang.(Narda, 2008)

Sebagai kota yang dijuluki dengan kota Serambi Mekkah, pemerintah daerah kota Padang Panjang berupaya untuk menjalankan syari'at Islam di berbagai bidang termasuk dalam pengelolaan pasar. Salah satu bentuk upaya pemerintah daerah kota Padang Panjang dalam pengelolaan pasar adalah dengan menghimbau masyarakat Padang Panjang untuk tidak melakukan penipuan melalui papan iklan yang terpampang di tengah-tengah kota sejak tahun 2008. Papan tersebut bertuliskan surat al-Muthaffifin ayat 1-3. Selain itu di depan kantor Pengelola Pasar juga terlihat papan 
iklan yang bertuliskan "untuk mewujudkan perdagangan yang Islami tera dan tera ulanglah alat ukur, takar, timbang, dan perlengkapan anda secara berkala”.

Menurut Hadi Siswanto, pegawai Dinas Koperasi dan Perdagangan mengatakan bahwa pemerintah juga melakukan sosialisasi tentang takaran dan timbangan sebanyak dua kali dalam satu tahun, agar masyarakat lebih memahami mengenai takaran dan timbangan.(H. Siswanto, komunikasi pribadi, 14 Januari 2020). Meskipun pemerintah daerah kota Padang Panjang telah berupaya untuk menjalankan syari'at Islam di bidang perdagangan seperti melakukan himbauan, sosialisasi, dan melakukan tera \& tera ulang alat ukur, takaran, timbangan dan perlengkapan, namun menurut salah seorang pegawai Dinas Koperasi Perindustrian dan Perdagangan kota Padang Panjang masih terdapat pedagang yang memakai alat ukur, takaran, timbangan, dan perlengkapan yang tidak sesuai dengan standar yang telah ditetapkan undang-undang. Hal ini menyebabkan alat ukur, takaran, timbangan, dan perlengkapan menjadi tidak akurat dan terjadi kecurangan dalam penggunaannya. Para pedagang juga tidak semuanya melakukan tera \& tera ulang, hal itu dapat dilihat dari penurunan jumlah pedagang yang mendaftar melakukan tera \& tera ulang dari tahun sebelumnya.(E. Sulastri, komunikasi pribadi, 14 Januari 2020).

Di lain pihak, para pedagang mengatakan bahwa tidak seluruh timbangan yang ditera \& tera ulang, hanya timbangan yang besar saja yang ditera \& tera ulang oleh petugas.(Tomi, komunikasi pribadi, 14 Januari 2020) Hal ini menunjukkan bahwa tidak seluruh masyarakat paham tentang tera dan tera ulang meskipun telah dilakukan sosialisasi oleh pemerintah. Selain itu, Ibu Elly mengatakan bahwa ketika beliau membeli $1 \mathrm{~kg}$ bawang, beliau mengukur kembali dengan timbangan lain hanya berjumlah 8 ons saja. Hal demikian tidak hanya sekali atau dua kali beliau uji.(Elly, komunikasi pribadi, 14 Januari 2020)

Selain pernyataan dari para pembeli, penulis melakukan observasi awal dengan mencoba pengujian langsung dengan cara membeli beberapa komoditi. Pada komoditi pertama pedagang tersebut menyatakan sudah pas $1 \mathrm{~kg}$ di saat jarum timbangan masih goyang-goyang. Kemudian pada komoditi lain, awalnya belum cukup 1ons ditimbang oleh pedagang, setelah itu pedagang menambahkan sedikit lagi, namun tidak mengulangi penimbangannya kembali. Penulis juga menemukan adanya pedagang yang menggunakan timbangan yang tidak layak pakai, yaitu timbangan yang tidak dimulai dengan angka nol pada jarum timbangan tersebut. Hal ini tentu akan merugikan konsumen yang membeli sebuah komoditi kepada pedagang tersebut.

Karena perbedaan pernyataan yang diungkapkan antara Dinas Koperasi Perindustrian dan Perdagangan kota Padang Panjang dengan pedagang di pasar 


\section{Peran Pemerintah Daerah dalam Mengawasi Takaran dan Timbangan dari Perspektif Ekonomi Syariah}

Tezi Asmadia

Padang Panjang dan melihat langsung bahwa ada pedagang yang tidak memakai timbangan sesuai standar penulis ingin membahasnya lebih lanjut.

\section{Tinjauan Teoritik}

Setiap orang akan berusaha untuk memenuhi kebutuhan hidupnya baik dengan menggunakan jasa maupun dengan mengonsumsi barang tertentu yang tersedia di pasar (Abdullah, 2014). Pasar adalah tempat atau keadaan yang mempertemukan antara permintaan (pembeli) atau penawaran (penjual) untuk setiap jenis barang, jasa atau sumber daya (A Karim, 2007). Dalam ilmu ekonomi pasar berkaitan dengan kegiatannya bukan tempatnya.

Dalam Islam pasar sangat menjadi perhatian karena pasar memiliki fungsi sebagai tempat berlangsungnya aktivitas jual beli. Islam mengakui jual beli sebagai salah satu aktivitas perekonomian yang sangat penting (A Karim, 2007). Perhatian Islam terhadap jual beli dijelaskan dalam al-Quran surat al-Baqarah ayat 275:

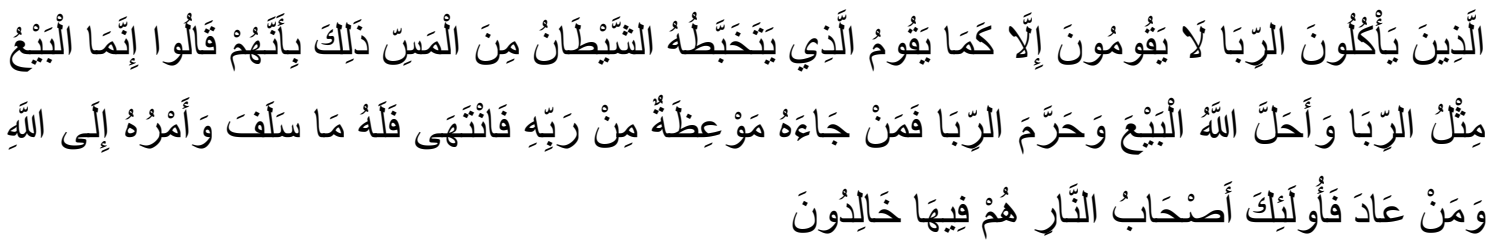

Artinya: Orang-orang yang makan (mengambil) riba tidak dapat berdiri melainkan seperti berdirinya orang yang kemasukan syaitan lantaran (tekanan) penyakit gila. Keadaan mereka yang demikian itu, adalah disebabkan mereka berkata (berpendapat), sesungguhnya jual beli itu sama dengan riba, padahal Allah telah menghalalkan jual beli dan mengharamkan riba. orang-orang yang telah sampai kepadanya larangan dari Tuhannya, lalu terus berhenti (dari mengambil riba), maka baginya apa yang telah diambilnya dahulu (sebelum datang larangan); dan urusannya (terserah) kepada Allah. orang yang kembali (mengambil riba), maka orang itu adalah penghuni-penghuni neraka; mereka kekal di dalamnya.

Selain fungsi pasar secara fisik sebagai tempat berlangsungnya kegiatan jual beli, aturan dan norma yang berhubungan dengan masalah pasar juga menjadi perhatian, hal ini disebabkan karena pasar rentan dengan adanya ketidakjujuran dan ketidakadilan. Oleh karena itu, pasar tidak terlepas dari aturan syari'at Islam. Berdagang adalah aktivitas yang paling umum dilakukan di pasar. Untuk itu teks-teks al Qur'an selain memberikan stimulasi imperatif untuk berdagang, di lain pihak juga mencerahkan aktivitas tersebut dengan sejumlah rambu atau aturan main yang bisa diterapkan di pasar dalam upaya menegakkan kepentingan semua pihak, baik individu maupun kelompok. 
Nilai-nilai moralitas mutlak harus ditegakkan agar mekanisme pasar dapat berjalan dengan baik dan memberikan mutual goodwill bagi para pelakunya. Persaingan yang sehat, kejujuran, keterbukaan, dan keadilan adalah nilai moralitas yang mendapat perhatian penting dalam pasar secara khusus. Nilai-nilai moralitas ini memiliki akar yang kuat dalam al-Qur'an. Oleh karena itu beberapa larangan terhadap praktik-praktik bisnis negatif yang dapat mengganggu mekanisme pasar yang islami telah ditetapkan Rasulullah (P3EI, 2014).

\section{Metode Penelitian}

Untuk menelaah peran pemerintah kota Padang Panjang dalam mengawasi takaran dan timbangan, jenis penelitian yang digunakan adalah penelitian lapangan (field research). Penelitian ini menggunakan beberapa sumber data yaitu sumber data primer dan sumber data sekunder. Sumber data primer yaitu sumber data yang diperoleh dari Dinas Koperasi Perindustrian dan Perdagangan kota Padang Panjang yaitu staf dinas koperindag yang membidangi takaran dan timbangan serta para pedagang yang menggunakan takaran dan timbangan sebanyak 20 orang yang menjual beras, sayur, dan buah. Sedangkan sumber data sekunder yaitu data pendukung dari data primer yang diperoleh dengan cara menelaah tulisan-tulisan atau artikel-artikel yang ada kaitannya dengan takaran dan timbangan.

Adapun dalam pengumpulan data, penulis menggunakan teknik pengumpulan data sebagai berikut, yaitu: observasi mengamati langsung cara para pedagang menimbang di pasar secara sistematis agar dapat diperoleh informasi mengenai perilaku pedagang dalam menimbang; wawancara merupakan proses mendapatkan informasi untuk sasaran penelitian melalui diskusi sambil bertatap muka antara penanya dan responden dengan menggunakan alat yang disebut interview guide (panduan wawancara). Wawancara dalam penelitian ini dilakukan dengan pihak Dinas Koperasi Perindustrian dan Perdagangan kota Padang Panjang serta dengan para pedagang yang menggunakan takaran dan timbangan; dokumentasi, dalam penelitian ini, dokumen yang penulis gunakan adalah Peraturan Daerah Kota Padang Panjang dan foto; dan kuesioner. teknik kuesioner dengan menyebarkan kuesioner kepada para pedagang yang menggunakan takaran dan timbangan untuk mengetahui tingkat pemahaman pedagang mengenai takaran dan timbangan.

Metode pengambilan responden yang digunakan dalam penelitian ini adalah dengan pendekatan non probability sampling melalui teknik penarikan sampel aksidental yaitu teknik penarikan yang didasarkan pada kemudahan (convenience). 


\section{Peran Pemerintah Daerah dalam Mengawasi Takaran dan Timbangan dari Perspektif Ekonomi Syariah}

Tezi Asmadia

Sampel dapat terpilih karena pada waktu, situasi, dan tempat yang tepat. (Prasetyo \& Jannah, 2014)

Suharsimi Arikunto menjelaskan apabila subjek kurang dari 100, lebih baik diambil semuanya. Selanjutnya dapat diambil dengan nilai 10\% - 15\% atau 20\% - 25\% atau lebih jika subjek lebih dari 100 (Arikunto, 2010). Karena total pedagang yang menggunakan takaran dan timbangan sebanyak 209 orang, maka sampel yang diambil sebanyak 20 orang.

Pengujian ini untuk mengukur sejauh mana kemampuan instrumen penelitian dapat digunakan dengan baik berdasarkan kadar validitasnya. Dalam pengujian validitas dan reliabilitas dilakukan percobaan terhadap instrumen penelitian uji coba terhadap 20 orang. Adapun untuk perhitungannya menggunakan rumus Aiken's V. Aiken merumuskan formula ini untuk menghitung content-validity coofficient yang didasarkan pada hasil penilaian sebanyak $\mathrm{n}$ orang terhadap suatu item dari sejauh mana item tersebut mewakili konten yang diukur. Formula yang diajukan oleh Aiken adalah:(Azwar, 2014). Nilai koefisien Aiken's V berkisar antara 0-1. Bila hasil koefisien berada pada kisaran angka o-1 sudah dapat dianggap memiliki validitas yang memadai. Setiap butir pertanyaan/pernyataan per variabel dimasukkan disertai dengan jumlah skor tiap butir pertanyaan/pernyataan. Dengan demikian validitas menunjukkan ukuran yang benar-benar mengukur apa yang akan diukur. Jadi dapat dikatakan semakin tinggi validitas suatu alat tes, maka alat tes tersebut semakin mengenai pada sasarannya atau semakin menunjukkan apa yang seharusnya diukur. Suatu tes dapat dikatakan mempunyai validitas tinggi, bila tes yang dilakukan melaksanakan fungsi ukurnya atau memberikan hasil ukur berdasarkan makna dan tujuan diadakannya tes tersebut. Jika peneliti menggunakan kuesioner di dalam pengumpulan data penelitian, maka item-item yang disusun pada kuesioner tersebut merupakan alat tes yang harus mengukur apa yang menjadi tujuan penelitian.

\section{Hasil Dan Pembahasan}

\section{Peran Pemerintah Daerah Kota Padang Panjang dalam Mengawasi} Takaran dan Timbangan

Islam dengan kesempurnaan, kemuliaan, dan keluhuran ajarannya, memerintahkan umatnya untuk menjalin muamalah dengan sesama atas dasar keadilan dan keridhaan. Di antaranya, dengan menyempurnakan timbangan dan takaran. Allah berfirman:

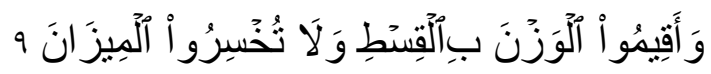


Artinya: Dan tegakkanlah timbangan itu dengan adil dan janganlah kamu mengurangi neraca itu (Q.S ar-Rahman: 9)

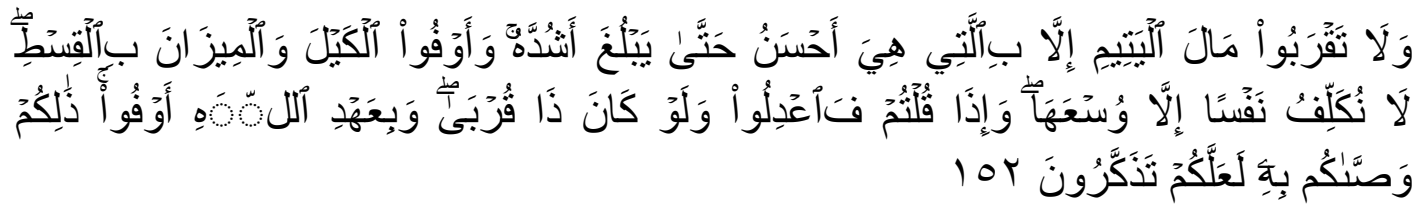

Artinya: Dan janganlah kamu dekati harta anak yatim, kecuali dengan cara yang lebih bermanfaat, hingga sampai ia dewasa. Dan sempurnakanlah takaran dan timbangan dengan adil. Kami tidak memikulkan beban kepada seseorang melainkan sekedar kesanggupannya. Dan apabila kamu berkata, maka hendaklah kamu berlaku adil, kendatipun ia adalah kerabat(mu), dan penuhilah janji Allah. Yang demikian itu diperintahkan Allah kepadamu agar kamu ingat

Melalui ayat ini, Allah memerintahkan penyempurnaan (isi) takaran dan timbangan dengan adil. Dan menyatakan bahwa siapa saja yang tanpa kesengajaan terjadi kekurangan pada takaran dan timbangannya, tidak mengapa karena tidak disengaja.

Mewujudkan ekonomi yang berbasis Islam berada di tangan pemerintah sebagai kewajiban secara kelembagaan. Fardu kifayah ini sangat terkait dengan kemaslahatan umum yang mencakup pada dharuriyat dan hajiyyat. Oleh karena itu, pemerintah sebagai khalifah memiliki kewajiban untuk mewujudkan ekonomi berbasis syariah salah satunya dengan mengawasi takaran dan timbangan.

Secara garis besar peran pemerintah dalam pasar dapat dibagi menjadi tiga, yaitu (Suntana, 2010).

1. Tanzhim ad Daulah (Pembuat Aturan), meskipun suatu perilaku yang Islami sangat diharapkan dalam sebuah masyarakat yang Islami, namun keikutsertaan intervensi pemerintah akan menjadikan implementasi nilai dan moralitas Islam menjadi lebih efektif. Pada dasarnya mekanisme kerja pasar tidak memiliki sistem otomatis yang berhubungan langsung dengan moralitas, meskipun moralitas sangat penting bagi optimumnya mekanisme kerja pasar. Teori diubah menjadi kenyataan, norma-norma diubah menjadi undang-undang, dan keindahan etika dipindahkan menjadi praktek sehari-hari adalah menjadi tugas pemerintah.

2. At Tawazun al-Ijtima'I, tugas pemerintah adalah membuat suatu badan khusus yang bertugas mengawasi dan meningkatkan kualitas ekonomi, mengadili orang yang melanggar, dan menegur orang yang lalai (Qardawi, 2006). 


\section{Peran Pemerintah Daerah dalam Mengawasi Takaran dan Timbangan dari Perspektif Ekonomi Syariah}

Tezi Asmadia

3. At Tadakhul ad-Daulah (Intervensi Negara), intervensi negara adalah negara mengintervensi aktivitas ekonomi untuk menjamin adaptasi hukum Islam yang berhubungan dengan aktivitas ekonomi masyarakat (Suntana, 2010). Seperti, praktek jual beli air milik umum, praktik usaha dengan menggunakan skema bunga, atau penguasaan lahan terlantar bukan untuk kegiatan profitabel.

Di Kota Padang Panjang, hal-hal yang berkaitan dengan pasar, seperti pembangunan pasar, pemungutan retribusi pasar, dan tata kelola pasar diatur oleh Kantor Pengelolaan Pasar. Kantor Pengelolaan Pasar tidak mengatur hal yang berkaitan dengan ketersediaan barang dan jasa, harga, dan UTTP.(Doni, komunikasi pribadi, 15 Januari 2020)

Pengawasan terhadap takaran dan timbangan di Kota Padang Panjang dilakukan oleh Balai Metrologi Dinas Koperasi Perindustrian dan Perdagangan. Pelaksanaan tugas Balai Metrologi memegang peranan yang sangat penting untuk terciptanya tertib ukur. Dengan terciptanya tertib ukur maka akan tercipta pula tertib niaga. Kondisi ini merupakan kondisi yang sangat didambakan oleh semua pihak. Masyarakat sebagai konsumen menginginkan adanya keadilan dalam transaksi dagang. Pemerintah sebagai pelaksana tugas kemetrologian menginginkan adanya kepatuhan pedagang dalam melaksanakan ketentuan dan peraturan yang berkaitan dengan takaran dan timbangan, sehingga tugas mereka dalam menegakkan tertib ukur dapat dicapai.

Tugas Balai Metrologi Legal sebagai lembaga yang ditugaskan negara yakni Menteri Perindustrian dan Perdagangan adalah:(Rozalinda, 2014)

1. Mengelola standar ukuran dalam bentuk pemeriksaan alat alat Ukuran, Takaran, Timbangan, dan Peralatannya (UTTP), pengujian terhadap UTTP, melakukan tera dan tera ulang UTTP,

2. Pengawasan alat UTTP

3. Penyuluhan kemetrologian.

4. Pengawasan barang dalam keadaan terbungkus.

Tugas pengawasan dan penyuluhan kemetrologian merupakan tugas yang dilakukan dalam upaya mencegah terjadinya tindakan penyelewengan pemakaian alat ukur takar dan timbangan oleh pedagang yang membawa pada kecurangan dan penipuan dalam masalah takaran dan timbangan. Di samping itu tugas metrologi legal lainnya yakni memberikan penyuluhan kepada para pedagang tentang ketentuan yang mesti dilakukan berkaitan dengan penggunaan alat-alat ukuran, takaran, dan timbangan. 
Metrologi legal Dinas Koperasi Perindustrian dan Perdagangan Kota Padang Panjang hanya merambah dari segi keabsahan dan kebenaran alat-alat ukur, takar, dan timbangan yang dipakai para pedagang, tidak merambah pada perilaku dan cara pedagang mempergunakan alat alat tersebut, misalnya pedagang yang selalu meletakkan anak timbangan di atas piring timbangan sebelum barang dimasukkan ke dalam bak timbangan atau menghempaskan barang timbangan dengan cepat ke dalam bak timbangan dan langsung secara cepat pula mengepaskan berat barang di saat jarum timbangan masih bergoyang. Metrologi Legal Dinas Koperasi Perindustrian dan Perdagangan Kota Padang Panjang tidak dapat melakukan tindakan hukum bila alat timbangan yang dipakai oleh pedagang yang menimbang barang dagangannya dengan cara seperti ini bila timbangan yang dipakai adalah ber-Tanda Sah. Kewenangan Balai Metrologi Legal Dinas Koperasi Perindustrian dan Perdagangan Kota Padang Panjang melalui tugas pengawasan terhadap takaran dan timbangan adalah dalam upaya menegakkan tertib ukur. Melakukan penyuluhan kemetrologian adalah dalam upaya agar setiap orang melakukan hal-hal yang benar dan bermanfaat untuk semua orang. (H. Siswanto, komunikasi pribadi, 14 Januari 2020)

Padahal dalam kenyataannya cara menimbang yang dilakukan para pedagang seperti ini cenderung merugikan konsumen, karena berat barang tidak pas seperti dalam transaksi misalnya $1 \mathrm{~kg}$ hanya ditemukan beratnya 8 ons.(Salma, komunikasi pribadi, 15 Januari 2020) Hal itu merugikan konsumen, namun menurut Hadi Siswanto kasus-kasus seperti ini menjadi kewenangan badan perlindungan konsumen, karena berkaitan dengan perlindungan terhadap hak-hak konsumen. Badan Perlindungan Konsumen pun tidak dapat bertindak jika tidak ada laporan dari masyarakat.(H. Siswanto, komunikasi pribadi, 14 Januari 2020)

Jika dilihat dari peran pemerintah dalam ekonomi Islam, pemerintah Kota Padang Panjang telah melakukan sebagian besar peran tersebut khususnya mengenai takaran dan timbangan. Hal ini dapat dilihat dari berbagai sisi, yaitu: $(\mathrm{H}$. Siswanto, komunikasi pribadi, 14 Januari 2020)

1. Dari sisi pembuat aturan, Pemerintah Daerah Kota Panjang telah membuat Peraturan Daerah mengenai tera dan tera ulang takaran dan timbangan yaitu Peraturan Daerah Kota Padang Panjang Nomor 2 Tahun 2014 tentang Penyelenggaraan Tera dan/ atau Tera Ulang Alat-Alat Ukur, Takar, Timbang dan Perlengkapannya. 


\section{Peran Pemerintah Daerah dalam Mengawasi Takaran dan Timbangan dari Perspektif Ekonomi Syariah}

Tezi Asmadia

2. Dari sisi pembuat lembaga, Pemerintah Daerah Kota Padang Panjang telah memiliki lembaga yang mengawasi takaran dan timbangan yaitu Dinas Koperasi Perindustrian dan Perdagangan Kota Padang Panjang.

3. Dari sisi intervensi, Pemerintah Daerah Kota Padang Panjang melakukan pengawasan terhadap takaran dan timbangan. Pengawasan yang dilakukan Pemerintah Daerah Kota Padang Panjang yaitu Balai Metrologi Dinas Koperasi Perindustrian dan Perdagangan hanya dalam bentuk kebenaran dan keakuratan takaran dan timbangan yang digunakan pedagang yaitu melakukan tera dan tera ulang terhadap takaran dan timbangan, bukan mengawasi perilaku para pedagang dalam menakar dan menimbang. Dan memberi sanksi terhadap pedagang yang menggunakan takaran dan timbangan yang tidak sesuai aturan dengan menyita takaran dan timbangan tersebut.

Selain peran di atas, Pemerintah Daerah Kota Padang Panjang juga melakukan sosialisasi mengenai takaran dan timbangan pada saat tera dan tera ulang. Sebagai bentuk amr ma'ruf nahi munkar Pemerintah Daerah Kota Padang Panjang dalam hal ini dilakukan oleh Dinas Koperindag melakukan himbauan melakukan perdagangan sesuai syari'at melalui papan iklan yang terpasang di tengah pasar kota. Iklan berisikan ayat dan hadis tentang perilaku berdagang yang baik. Papan iklan tersebut di pasang kira-kira sejak tahun 2008.

\section{Pelaksanaan Tera dan Tera Ulang takaran dan Timbangan yang Dilakukan oleh Pemerintah Daerah Kota Padang Panjang}

Timbangan meja atau timbangan pegas adalah timbangan yang secara umum paling banyak dipakai di pasar Padang Panjang. Secara umum alasan pemilihan penggunaan timbangan ini adalah mudah dalam mengoperasikan dan kesesuaian/kecukupan kapasitas (Amir, komunikasi pribadi, 20 Januari 2020). Balai Metrologi Dinas Koperasi Perindustrian dan Perdagangan Kota Padang Panjang melaksanakan pelayanan di bidang Metrologi Legal khususnya secara rutin pelayanan tera/ tera ulang dan pengawasan kemetrologian di Padang Panjang setiap satu kali dalam satu tahun. Penyuluhan mengenai tera dan tera ulang dilakukan oleh Dinas Koperasi Perindustrian dan Perdagangan Kota Padang Panjang pada saat jadwal tera dan tera ulang dilakukan (H. Siswanto, komunikasi pribadi, 14 Januari 2020). Berdasarkan pengamatan penulis, penyuluhan yang dilakukan tidak kepada seluruh pedagang karena penyuluhan dilakukan tidak pada waktu khusus dengan mengumpulkan para pedagang. 
Sumber daya manusia dan biaya operasional yang besar tidak dibutuhkan dalam pelaksanaan aktivitas pelayanan tera/ tera ulang karena wilayah kota Padang Panjang yang tidak terlalu luas. Aktivitas pelayanan tera/ tera ulang yang sudah dilakukan selama ini sudah mencakup 4 kecamatan (H. Siswanto, komunikasi pribadi, 14 Januari 2020).

Dinas Koperindag masih menggunakan sumber daya dari UPTD provinsi dalam hal pengawasan. Selain melaksanakan pengawasan, UPTD provinsi juga melaksanakan pembinaan dan peneraan. Hal ini disebabkan oleh sumber daya manusia yang belum memadai. Saat ini yang berwenang melakukan tera dan tera ulang langsung dilakukan oleh UPTD Balai Metrologi Dinas Perindustrian dan Perdagangan Provinsi Sumatera Barat, sehingga dalam pelaksanaan tera dan tera ulang takaran dan timbangan mesti menyesuaikan dengan UPTD Balai Metrologi Pusat (H. Siswanto, komunikasi pribadi, 14 Januari 2020).

Pelayanan kemetrologian dilakukan dengan beberapa cara, yaitu sidang tera/tera ulang ke pasar (lokasi pemilik dan pengguna UTTP), pelayanan tera/tera ulang di pasar Padang Panjang, serta kunjungan ke lokasi tertentu di mana alat UTTP tidak dapat dipindahkan seperti SPBU. Pelaksanaan sidang tera membutuhkan waktu selama 5 hari kerja dengan anggaran sekitar Rp42.ooo.ooo,- dengan 6 (enam) orang penera. Peneraan dilakukan dengan cara mengumpulkan di suatu lokasi seperti di pos pasar atau kantor tidak dilakukan door to door. Pada tahun 2019 dilakukan di depan Mesjid Tauhid Pasar Baru Kota Padang Panjang dan Pasar Induk Hasil Pertanian.(H. Siswanto, komunikasi pribadi, 14 Januari 2020) Menurut pengamatan penulis jika dilihat dari sisi para pedagang hal ini tidak berjalan efektif karena menimbulkan antrian panjang membuat waktu para pedagang habis sehingga mereka malas untuk melakukan tera dan tera ulang.

Selain karena antrian yang panjang, pedagang juga mengeluhkan tera dan tera ulang malah merusak timbangan (Amir, komunikasi pribadi, 20 Januari 2020). Menurut pengamatan penulis kerusakan dan keluhan tersebut ditimbulkan oleh beberapa faktor, yaitu:

1. Reparatir bekerja tidak secara profesional,

2. Penera dan reparatir melaksanakan pekerjaan dengan tergesa-gesa karena waktu sedikit,

3. Pedagang memberi upah kepada buruh untuk membawa timbangan ke lokasi tera ulang karena adanya antrian, ketika dilakukan pemindahan timbangan menjadi rusak disebabkan penanganan yang tidak tepat. 


\section{Peran Pemerintah Daerah dalam Mengawasi Takaran dan Timbangan dari Perspektif Ekonomi Syariah}

Tezi Asmadia

4. Dibutuhkan sosialisasi mengenai cara menjaga dan menggunakan timbangan dengan benar, atau

5. Hanya sebagai dalih pedagang untuk merahasiakan timbangannya yang rusak.

Tidak ada pengawasan dan penyuluhan yang dilakukan di Padang Panjang, kecuali pada saat tera ulang dilakukan. Kegiatan pengawasan dan wawancara biasanya dilakukan bersamaan dengan pekan tera ulang. Jadi dua hari sebelum pelayanan tera dilaksanakan di suatu pasar, maka ada petugas dari Dinas Perdagangan, Pengelola Pasar, dan UPT Metrologi yang melakukan semacam sosialisasi kepada para pedagang bahwa tera ulang akan dilakukan (H. Siswanto, komunikasi pribadi, 14 Januari 2020).

Menurut keterangan Staf Dinas Koperindag Padang Panjang, jika ada pedagang yang melakukan ketidakjujuran dalam menimbang, maka hal yang dilaksanakan pertama kali adalah melakukan pembinaan, jika berulang maka takaran dan timbangan akan disita (H. Siswanto, komunikasi pribadi, 14 Januari 2020).

\section{Tingkat Pemahaman Pedagang Pasar Padang Panjang dalam Menggunakan Takaran dan Timbangan yang Benar Sesuai dengan Ekonomi Islam}

Untuk mengukur pemahaman pedagang teknik analisis yang digunakan berdasarkan skala pengukuran likert dan skala guttman berupa penggunaan model analisis rating skala di mana model analisis ini akan mengukur jawaban responden yang telah dikuantitatifkan dengan menentukan skor tertinggi (Sugiyono, 2008). Berdasarkan interval skala yang diperoleh, maka total skor jawaban yang diperoleh dimasukkan berdasarkan tabulasi sehingga dapat diketahui posisi adanya kesesuaian persepsi kepuasan nasabah terhadap pemahaman masyarakat Padang Padang Panjang. Rentang skala di susun berdasarkan dimensi-dimensi pemahaman pedagang yaitu interpretasi, memberikan contoh, dan menyimpulkan. Dengan demikian akan diketahui tingkat pemahaman masyarakat mengenai takaran dan timbangan di Padang Panjang.

Dalam penelitian ini, pemahaman masyarakat diukur dengan indeks pengetahuan masyarakat. Indeks ini dapat diketahui dari hasil penilikan terhadap responden pedagang di pasar Padang Panjang sebanyak 20 responden. Pemahaman masyarakat dilihat dari beberapa variabel, yaitu: 


\section{Variabel Interpretasi}

Indikator dalam variabel ini adalah pemahaman tentang aturan takaran dan timbangan dalam ekonomi Islam dan undang-undang. Untuk variabel interpretasi digunakan skala pengukuran likert. Total skor pemahaman masyarakat terhadap variabel interpretasi adalah 478. Nilai ini menunjukkan responden paham terhadap takaran dan timbangan serta peraturan tentang takaran dan timbangan secara umum. Nilai 478 termasuk kategori interval "cukup paham dan paham". Tetapi lebih mendekati paham. Oleh karena itu, pemahaman pedagang terhadap takaran dan timbangan ini disebabkan oleh telah lamanya mereka menggunakan takaran dan timbangan. Mereka menggunakan takaran dan timbangan bertahun-tahun (H. Jamal, komunikasi pribadi, 15 Januari 2020).

\section{Variabel memberikan contoh}

Indikator dalam variabel ini adalah pedagang dapat memberikan contoh menggunakan takaran dan timbangan sesuai syariat dan takaran dan timbangan sesuai aturan. Total skor pemahaman masyarakat terhadap variabel memberikan contoh adalah 160. Nilai ini menunjukkan responden paham terhadap contoh menggunakan takaran dan timbangan sesuai syariat dan takaran dan timbangan sesuai aturan. Jumlah skor kriterium yaitu diperoleh dari nilai teratas $\mathrm{x}$ total poin pertanyaab x total responden. Nilai 160 termasuk kategori interval "paham dan sangat paham”. Tepat pada interval paham. Maka pada indikator ini pedagang dinyatakan paham. Dengan demikian, pedagang paham bahwa dalam Islam tidak boleh curang dalam menakar dalam menimbang. Dalam menakar dan menimbang tentunya harus pas (Amir, komunikasi pribadi, 20 Januari 2020). Akan tetapi pedagang belum paham bahwa jika timbangan rusak tidak boleh dipakai lagi. Seperti yang penulis temukan adanya salah seorang pedagang yang menggunakan timbangan yang tidak dimulai dengan angka nol.

\section{Variabel Menyimpulkan}

Indikator dalam variabel ini adalah pedagang dapat menyimpulkan bahwa takaran dan timbangan harus sesuai aturan yang berlaku. Rataan skor pemahaman masyarakat terhadap variabel menyimpulkan adalah 250. Nilai ini menunjukkan responden sangat paham terhadap takaran dan timbangan serta peraturan tentang takaran dan timbangan secara umum. Nilai 250 termasuk kategori interval "paham dan sangat paham". Tetapi lebih mendekati paham. Maka pada indikator ini pedagang dinyatakan paham. 


\section{Peran Pemerintah Daerah dalam Mengawasi Takaran dan Timbangan dari Perspektif Ekonomi Syariah}

\section{Variabel Pemahaman Dasar}

Beberapa indikator dalam variabel ini adalah pemahaman tentang jenis takaran dan timbangan, pemahaman tentang penggunaan takaran dan timbangan, pemahaman tentang aturan mengenai takaran dan timbangan, pemahaman tentang takaran dan timbangan dalam ekonomi Islam. Total skor pemahaman masyarakat terhadap variabel pemahaman dasar adalah 75. Nilai ini menunjukkan responden cukup paham terhadap takaran dan timbangan secara umum. Nilai 75 termasuk kategori interval "cukup paham dan paham". Tetapi lebih mendekati cukup paham. Maka pada indikator ini pedagang dinyatakan cukup paham.

\section{Variabel Pengawasan terhadap Takaran dan Timbangan}

Indikator dalam variabel ini adalah pemahaman tentang aturan takaran dan timbangan dalam ekonomi Islam dan undang-undang. Total skor pemahaman masyarakat terhadap variabel pengawasan takaran dan timbangan adalah 73. Nilai ini menunjukkan responden cukup paham terhadap peraturan tentang takaran dan timbangan secara umum. Nilai 75 termasuk kategori interval "cukup paham dan paham”. Tetapi lebih mendekati cukup paham. Maka pada indikator ini pedagang dinyatakan cukup paham.

Jika digabungkan skor skala likert dan skala guttman untuk memperoleh tingkat pemahaman secara keseluruhan, maka pedagang di pasar Padang Panjang cukup paham dengan takaran dan timbangan dan aturannya. Hasil ini sesuai dengan jawaban responden ketika penulis menanyakan kembali jawaban yang mereka jawab paham dan sangat paham. Seperti ketika mereka paham jika ditanya tentang timbangan yang tidak layak pakai, namun ketika ditanya apakah boleh menggunakan timbangan yang anak timbangan telah hilang dan diganti dengan benda lain yang seukuran mereka menjawab boleh.(Wismon, komunikasi pribadi, 16 Januari 2020) Hal ini membuktikan bahwa mereka sebenarnya belum memahami betul tentang takaran dan timbangan. Mereka hanya melakukan kegiatan yang sudah dilakukan berulang kali tanpa memahami hakikat sebenarnya dari takaran dan timbangan itu sendiri.

\section{Kesimpulan}

Setelah dilakukan pembahasan sebagaimana diuraikan pada bagian sebelumnya, maka dapat diambil kesimpulan sebagai berikut: pertama, pengawasan terhadap takaran dan timbangan di Kota Padang Panjang dilakukan oleh Balai 
Metrologi Dinas Koperasi Perindustrian dan Perdagangan. Pelaksanaan tugas Balai Metrologi memegang peranan yang sangat penting untuk terciptanya tertib ukur. Metrologi legal hanya merambah dari segi keabsahan dan kebenaran alat-alat ukur, takar dan timbangan yang dipakai para pedagang, tidak merambah pada perilaku dan cara pedagang mempergunakan alat alat tersebut. Kedua, dalam hal pengawasan, Dinas Koperindag masih memanfaatkan sumber daya dari UPTD provinsi yang pada dasarnya juga melakukan pembinaan dan peneraan. Hal ini disebabkan karena sumber daya manusia yang belum memadai. Saat ini yang berwenang melakukan tera dan tera ulang langsung dilakukan oleh UPTD Balai Metrologi Dinas Perindustrian dan Perdagangan Provinsi Sumatera Barat, sehingga dalam pelaksanaan tera dan tera ulang takaran dan timbangan mesti menyesuaikan dengan UPTD Balai Metrologi Pusat. Ketiga, pedagang pasar Padang Panjang cukup paham dalam menggunakan takaran dan timbangan yang benar sesuai dengan ekonomi Islam.

\section{Daftar Pustaka}

A Karim, A. (2007). Ekonomi Mikro Islami. PT RajaGrafindo Persada.

Abdullah, M. M. (2014). Manajemen Bisnis Syariah. Aswaja Pressindo.

Amir. (2020, Januari 20). [Komunikasi pribadi].

Arikunto, S. (2010). Prosedur Penelitian Suatu Pendekatan Praktek. Rineka Cipta.

Azwar, S. (2014). Reliabilitas dan Validitas. Pustaka Pelajar.

Doni. (2020, Januari 15). [Komunikasi pribadi].

Elly. (2020, Januari 14). Peran Pemerintah Daerah Kota Padang Panjang dalam Mengawasi Takaran dan Timbangan Ditinjau dari Perspektif Ekonomi Syariah [Komunikasi pribadi].

Hafidhuddin, D., \& Tanjung, H. (2003). Manajemen Syariah dalam Praktik. Gema Insani.

Jamal, H. (2020, Januari 15). [Komunikasi pribadi].

Narda, B. (2008, September 6). Menguak Misteri Padang Panjang Kota Serambi Mekkah. https:// id- id. facebook. com/ permalink. php? story_ fbid= $268150906589259 \& i d=182249501881737$.

P3EI. (2014). Ekonomi Islam. PT RajaGrafindo Persada.

Prasetyo, B., \& Jannah, L. M. (2014). Metode Penelitian Kuantitatif. PT RajaGrafindo Persada.

Qardawi, Y. (2006). Daurul Qiyam wa al-Akhlaq fi al Iqtishadi al Islami. Gema Insani. 


\section{Peran Pemerintah Daerah dalam Mengawasi Takaran dan Timbangan dari Perspektif Ekonomi Syariah}

Tezi Asmadia

Rozalinda, R. (2014). Ekonomi Islam Teori dan Aplikasinya pada Aktivitas Ekonomi. Salma. (2020, Januari 15). [Komunikasi pribadi].

Siswanto, H. (2020, Januari 14). Peran Pemerintah Daerah Kota Padang Panjang dalam Mengawasi Takaran dan Timbangan Ditinjau dari Perspektif EKonomi Syariah [Komunikasi pribadi].

Sugiyono. (2008). Metode Penelitian Bisnis, (Pendekatan Kuantitatif, Kualitatif dan $R \& D)$. Penerbit Alfabeta.

Sugiyono. (2013). Metode Penelitian Kombinasi. Alfa Beta.

Sulastri, E. (2020, Januari 14). Peran Pemerintah Daerah Kota Padang Panjang dalam Mengawasi Takaran dan Timbangan Ditinjau dari Perspektif Ekonomi Syariah [Komunikasi pribadi].

Suntana, I. (2010). Politik Ekonomi Islam Teori- Teori Pengelolaan Sumber Daya Alam, Hukum Pengairan Islam, dan Undang-Undang Sumber Daya Air di Indonesia. CV Pustaka Setia.

Tomi. (2020, Januari 14). Peran Pemerintah Daerah Kota Padang Panjang dalam Mengawasi Takaran dan Timbangan Ditinjau dari Perspektif Ekonomi Syariah [Komunikasi pribadi].

Wismon. (2020, Januari 16). [Komunikasi pribadi]. 